these were probably outweighed by the more frequent admissions to the emergency room by ambulance in the placebo group. Thus excluding costs of non-severe side effects and transportation probably did not influence the overall result.

The most obvious economic gain with long term metoprolol was in the reduction of indirect costs. Direct costs (costs of readmission), however, were also lower in the metoprolol group compared with the placebo group. The difference between the two groups became most evident later in follow up.

As any evaluation of costs and benefits of a treatment requires many different assumptions, we performed a sensitivity analysis using various discount rates. At discount rates ranging between $2.5 \%$ and $8.0 \%$ metoprolol was associated with reduced overall costs. We did not set out to achieve exact costs for the two different treatment regimens, as the analysis needed to be based on several assumptions, and costs differ in different health care systems. The important finding was that prophylactic treatment with the $\beta$ blocking agent metoprolol given for three years after myocardial infarction did not increase costs but reduced utilisation of the health care system.

We do not know what the effects of metoprolol might be if it were to be continued beyond three years after myocardial infarction. That patients with infarction treated with $\beta$ blockade have a longer survival may result in higher utilisation of the health care system in a later phase. These possible future costs, however, will probably include an increased need for health care owing to aging of the patients.

In conclusion, three years of metoprolol treatment given after myocardial infarction improved the prognosis and reduced utilisation of the health care system. Postinfarction treatment with metoprolol therefore appears to be cost effective.

\section{References}

1 May GS, Eberlein KA, Furberg CD, Passamani ER, DeMets L. Secondary prevention after $\overparen{D}$ myocardial infarction: a review of longterm trials. Prog Cardiovasc Dis 1982;24:331-51.

2 Wilhelmsson C, Vedin JA, Elmfeldt D, Tibblin G, Wilhelmsen L. Smoking and myocardial T infarction. Lancet 1975; i:415-20.

3 Norwegian Multicenter Study Group. Timolol-induced reduction in mortality and reinfarction in :patients surviving acute myocardial infarction. N Engl Y Med 1981;304:801-7.

$4 \mathrm{Hjalmarson} \AA$, Elmfeldt D, Herlitz J, et al. Effect on mortality of metoprolol in acute myocardial $\stackrel{\rho}{\rightarrow}$

infarction. A double-blind randomised trial. Lancet 1981;ii:823-7.
5 Beta-blocker Heart Attack Trial Research Group. A randomized trial of propranolol in patients with acute myocardial infarction. I. Mortality results. JAMA 1982:247:1707-14.
int

6 Olsson G, Rehnqvist N, Siögren A, Erhardt L, Lundman T. Longterm treatment with metoprolol $\frac{\overline{\mathcal{D}}}{\overline{\mathrm{S}}}$ after myocardial infarction: effect on 3 year mortality and morbidity. JACC 1985;5:1428-37. Breckenridge A. Should every survivor of a heart attack be given a beta-blocker? Part II. Evidence Breckenridge $A$. Should every survivor of a heart attack be given a beta- $b$

from a clinical pharmacological standpoint. Br Med f 1982;285:37-9.

8 Rose G. Prophylaxis with beta-blockers and the community. Br J Clin Pharmacol 1982;14:45-8S. O 9 Olsson G, Lubsen J, van Es G-A, Rehnqvist N. Quality of life after acute myocardial infarction: $\vec{O}$ effects of chronic metoprolol treatment on mortality and morbidity. BrMed J 1986;292:1491-3. 10 Landstingsförbundet. Kostnad per intagen vårddag och läkarbesök 1982. Stockholm: Swedish $\vec{\omega}$ Federation of County Councils, 1984.

11 Statistiska Centralbyrån (SCB). Statistiska meddelanden Be20 SM 8501. Stockholm: Statistics $\frac{\mathscr{O}}{\partial}$ Sweden, 1985.

12 Olsson G, Rehnqvist N. Evaluation of anti-arrhythmic effect of metoprolol treatment after acute myocardial infarction: relationship between treatment responses and survival during a 3-year follow-up. Eur Hean f 1986;7:312-9.

13 Goldman L, Cook EF, Mitchell N, Flatley M, Sherman H, Cohn P. Pitfalls in the serial assessment of cardiac functional states: how a reduction of "ordinary" activity may reduce the $\mathrm{G}$ apparent degree of cardiac compromise and give a misleading impression of improvement. O J Chronic Dis 1982;35:763-71.

(Accepted 25 November 1986)

\title{
Type I (insulin dependent) diabetes: a disease of slow clinical onset?
}

\author{
ANNE C TARN, CLAIRE P SMITH, KATE M SPENCER, GIAN FRANCO BOTTAZZO, \\ EDWIN A M GALE
}

\begin{abstract}
Type I (insulin dependent) diabetes is usually believed to present acutely and it is assumed that metabolic decompensation is sudden. In a prospective family study, however, 10 of 13 subjects developing the disease showed progressive or intermittent development of hyperglycaemia over many months and the others had non-specific symptoms over a long period. All were first degree relatives of a child with type I diabetes; 10 were siblings (aged 5-24) and three were parents (aged 45-58). All possessed HLA-DR4 or DR3, or both, and all but two had been positive for islet cell antibodies for six to 86 months before diagnosis. Ten had non-specific symptoms for two to 14 months before the onset of thirst and polyuria; one remained asymptomatic even when insulin became necessary. Six subjects had an
\end{abstract}

\footnotetext{
Department of Diabetes and Immunogenetics, St Bartholomew's Hospital, London EC1A 7BE

ANNE C TARN, MRCP, research registrar

CLAIRE P SMITH, MRCP, research registrar

KATE M SPENCER, MRCP, senior registrar

EDWIN A M GALE, MRCP, consultant physician

Department of Immunology, Middlesex Hospital, London W1

GIAN FRANCO BOTTAZZO, MD, MRCP, reader in clinical immunology

Correspondence to: Dr Gale.
}

oral glucose tolerance test before clinical onset, of whom five were diabetic by World Health Organisation criteria four, four, six, seven, and 21 months before insulin was needed. Nine showed random blood glucose concentrations above the 97.5 th 0 centile $(6.3 \mathrm{mmol} / \mathrm{l})$ six to 34 months (median 12) before diagnosis. Two others had a glucose tolerance test result $\delta$ compatible with diabetes but had not reached the stage of $₹$ needing insulin.

Hyperglycaemia is often of insidious onset in type I diabetes, even in children and young adults. Diagnosis will inevitably be late if considered only when acute symptoms of thirst ando polyuria develop.

\section{Introduction}

Traditionally type I (insulin dependent) diabetes is thought to present acutely, especially in childhood. The most recent edition of ${ }^{+}$ a standard paediatric textbook states that "the onset of diabetes in childhood is always acute with thirst and polyuria as the presenting $\underset{\mathbb{D}}{\stackrel{+}{*}}$ symptoms." In practice the presentation of childhood diabetes may

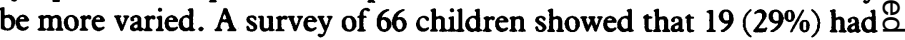
symptoms for less than two weeks, $18(27 \%)$ had symptoms for two to four weeks, and 29 (44\%) had symptoms for more than fouro weeks. ${ }^{2}$

More recent studies have shown that the onset of type I diabetes is preceded by a prodromal period, often extending over years, 
characterised by the presence of circulating islet cell antibodies ${ }^{3}$ and abnormalities of cell mediated immunity. ${ }^{4}$ Another feature of this period is progressive loss of the first phase insulin response to intravenous glucose. ${ }^{5}$ These observations suggest slow attrition of the numbers or function of $\beta$ cells culminating in obvious metabolic decompensation only when some $80-90 \%$ of cells have been destroyed. If this is correct we could predict that many patients will drift into diabetes and that acute onset will be exceptional and related to acute intercurrent illness or other forms of stress.

We have had the opportunity to study the onset of glucose intolerance and symptomatic diabetes prospectively in first degree relatives of children with type I diabetes. Over the past seven years we have observed the development of diabetes in 15 patients (two not having reached the stage of needing insulin). All had symptoms or biochemical abnormalities long before clinical presentation.

\section{Patients and methods}

The Barts-Windsor family study was established in 1978 and recruited 207 families with a diabetic proband diagnosed under the age of 20 . Families have been visited every four to six months and blood samples obtained from all members for blood glucose, islet cell antibody, and other measurements. ${ }^{3}$

Blood glucose concentrations reported here were measured from whole blood using a glucose oxidase-peroxidase method (Technicon AAII or Yellow Springs analyser). A normal range for random blood glucose values was obtained using all the samples measured in the non-diabetic family members in the study (roughly 800 samples); the 97.5 th centile for these was $6.3 \mathrm{mmol} / 1$. In one patient glucose values were measured in stored serum samples; the correlation of serum glucose with whole blood samples was: serum glucose $(\mathrm{mmol} / \mathrm{l})=1.01 \times$ whole blood glucose $-0.34(\mathrm{r}=0.99 ; \mathrm{n}=30)$.

Glycosylated haemoglobin was measured by cation exchange chromatography (Bio-Rad). The non-diabetic range in our laboratory is $3 \cdot 4-6 \cdot 1 \%$. Tests of glucose tolerance including oral glucose tolerance tests $(1.75 \mathrm{~g} / \mathrm{kg}$ body weight to a maximum of $75 \mathrm{~g}$ ) and $25 \mathrm{~g}$ intravenous glucose tolerance tests were performed in some subjects.

\section{Results}

During the study 10 siblings and three parents developed diabetes; al were established with insulin treatment. In only two was the onset of symptoms sudden, though both had shown abnormal glucose tolerance four and six months previously. The average duration of specific symptoms such as thirst and polyuria in the remainder was short (four weeks), while the duration of non-specific symptoms such as tiredness, weight loss, and irritability was longer (median 26 weeks). One remained asymptomatic even when insulin was required to control sustained hyperglycaemia. In addition, two others had glucose tolerance test results compatible with diabetes but did not require insulin. The table gives the details of all 15 subjects.

\section{CASE HISTORIES}

Case 5-An 11 year old boy first complained of tiredness in November 1984. Urine samples showed $2 \%$ glycosuria, and a random blood glucose estimation was $15.4 \mathrm{mmol} / \mathrm{l}$. He began following a $200 \mathrm{~g}$ carbohydrate diet and subsequent blood glucose concentrations ranged between 6.0 and $7 \cdot 3 \mathrm{mmol} / \mathrm{l}$. His glycosylated haemoglobin value was $4 \cdot 5 \%$ in June 1985 , and an oral glucose tolerance test gave the following results: $0 \mathrm{~min} 4.4 \mathrm{mmol} / \mathrm{l}$, $30 \mathrm{~min} 8.3 \mathrm{mmol} / \mathrm{l}, 60 \mathrm{~min} 11.4 \mathrm{mmol} / \mathrm{l}, 120 \mathrm{~min} 15.0 \mathrm{mmol} / \mathrm{l}$, and $180 \mathrm{~min}$ $7.6 \mathrm{mmol} / \mathrm{l}$. Results were similar six months later, and both sets of values were diabetic by World Health Organisation criteria but (because of the normal fasting blood glucose concentration) not by National Diabetes Data Group criteria ${ }^{67} \mathrm{He}$ remained asymptomatic, with random laboratory blood glucose measurements of $4 \cdot 2-7 \cdot 3 \mathrm{mmol} / \mathrm{l}$ until January 1986 , when he developed thirst and polyuria over a weekend. Home blood glucose measurements showed readings of $>22 \mathrm{mmol} / \mathrm{l}$ but urine was negative for ketones. He began taking insulin 14 months after the blood glucose concentration was first noted to be abnormal.

Case 12-Both the brother and mother (case 8) of this 15 year old girl had insulin-dependent diabetes. Apart from failure to gain weight (she weighed $35 \mathrm{~kg}$ (3rd centile for age) in September 1983 and $38 \mathrm{~kg}$ (well below the 3 rd centile) in January 1986) she remained asymptomatic. In September 1985 she underwent a minor operation and the wound was slow to heal. Two months later she complained of a sore throat and tiredness; infectious mononucleosis was considered but a Paul-Bunnell test gave a negative result. In January 1986 these symptoms recurred but she did not complain of thirst or polyuria. Blood glucose concentration was $32.4 \mathrm{mmol} / \mathrm{l}$ and the urine contained a moderate amount of ketones. Retrospective analysis of glucose values in stored serum samples gave the following results: September 1982 (five samples), 3.3-4.4 mmol/1; April 1983, $29 \cdot 4 \mathrm{mmol} /$; September $1983,31 \cdot 1 \mathrm{mmol} / 1$; May $1984,25 \cdot 7 \mathrm{mmol} / \mathrm{l}$; and January $1985,35 \cdot 0 \mathrm{mmo} / \mathrm{l}$. All of these samples were taken postprandially. Thus severe hyperglycaemia (recognised retrospectively) had been present for nearly three years before specific symptoms occurred.

Case 3-This 24 year old man shared at least one HLA haplotype with his

Characteristics of subjects developing insulin dependent diabetes

\begin{tabular}{|c|c|c|c|c|c|c|c|}
\hline $\begin{array}{l}\text { Case } \\
\text { No }\end{array}$ & $\begin{array}{l}\text { Sex and age (years) } \\
\text { at start of } \\
\text { insulin treatment }\end{array}$ & $\begin{array}{c}\text { HLA-DR } \\
\text { type }\end{array}$ & $\begin{array}{l}\text { Duration of islet cell antibody } \\
\text { before insulin treatment } \\
\text { (months) }\end{array}$ & $\begin{array}{c}\text { Random blood glucose concentration (RBG) } \\
>97 \cdot 5 \text { th centile and result of } \\
\text { oral glucose tolerance test (OGTT) }\end{array}$ & $\begin{array}{l}\text { Weeks } \\
\text { before insulin } \\
\text { treatment }\end{array}$ & Symptoms & $\begin{array}{l}\text { Weeks } \\
\text { before insulin } \\
\text { treatment }\end{array}$ \\
\hline 1 & M 9 & 1,4 & 36 & - & - & $\left\{\begin{array}{l}\text { Tiredness } \\
\text { Polyuria }\end{array}\right.$ & $\begin{array}{c}36 \\
1 \text { day }\end{array}$ \\
\hline 2 & F 23 & 3,3 & 50 & $\left\{\begin{array}{l}\text { RBG } 7 \cdot 7 \mathrm{mmol} / 1 \\
\text { OGTT "diabetic" }\end{array}\right.$ & $\begin{array}{l}52 \\
84\end{array}$ & Vaginal candidiasis & 28 \\
\hline 3 & M 24 & 3,3 & 84 & $\left\{\begin{array}{l}\text { RBG 7·3 mmol/1 } \\
\text { OGTT "diabetic" }\end{array}\right.$ & $\begin{array}{l}74 \\
16\end{array}$ & Asymptomatic & \\
\hline 4 & M 21 & 3,4 & 78 & $\left\{\begin{array}{l}\text { RBG } 6.4 \mathrm{mmol} / 1 \\
\text { OGTT normal } 4 \text { years before }\end{array}\right.$ & 36 & $\begin{array}{l}\text { Tiredness } \\
\text { Polyuria }\end{array}$ & $\begin{array}{r}16 \\
1\end{array}$ \\
\hline 5 & M 13 & 1,4 & 86 & $\left\{\begin{array}{l}\text { RBG } 15.4 \mathrm{mmol} / 1 \\
\text { OGTT "impaired" }\end{array}\right.$ & $\begin{array}{l}58 \\
30\end{array}$ & $\begin{array}{l}\text { Tiredness } \\
\text { Polyuria }\end{array}$ & $\begin{array}{r}58 \\
1\end{array}$ \\
\hline 6 & F 18 & 4,8 & 6 & $\left\{\begin{array}{l}\text { RBG } 6.7 \mathrm{mmol} / \mathrm{l} \\
\text { OGTT "impaired" }\end{array}\right.$ & $\begin{array}{l}26 \\
16\end{array}$ & Polyuria & 4 \\
\hline 7 & MS & $4, X$ & 30 & RBG 6.4 mmol/ & 28 & $\left\{\begin{array}{l}\text { Tiredness } \\
\text { Polyuria }\end{array}\right.$ & $\begin{array}{c}26 \\
4 \text { days }\end{array}$ \\
\hline 8 & F 45 & 3,4 & 57 & $\mathrm{RBG} 7 \cdot 2 \mathrm{mmo} / \mathrm{l}$ & 52 & $\left\{\begin{array}{l}\text { Polyuria } \\
\text { Failed oral agents }\end{array}\right.$ & $\begin{array}{r}8 \\
26\end{array}$ \\
\hline 9 & $\mathbf{M} 20$ & 3,4 & $23^{\star}$ & - & - & Weight loss & 8 \\
\hline 10 & M 61 & 4,4 & - & RBG 6.4 mmol/ & 157 & $\left\{\begin{array}{l}\text { Weight loss } \\
\text { Failed oral agents }\end{array}\right.$ & $\begin{array}{r}16 \\
104\end{array}$ \\
\hline 11 & F 12 & - & 80 & - & - & $\left\{\begin{array}{l}\text { Weight loss } \\
\text { Polyuria }\end{array}\right.$ & $\begin{array}{r}12 \\
4\end{array}$ \\
\hline $\begin{array}{l}12 \\
13\end{array}$ & $\begin{array}{l}\text { F } 16 \\
\text { F } 46\end{array}$ & $\begin{array}{l}3,8 \\
1,4\end{array}$ & $\overline{23}$ & $\begin{array}{l}\text { RBG } 29 \cdot 4 \mathrm{mmol} / / \\
\text { OGTT "diabetic" }\end{array}$ & $\begin{array}{r}144 \\
26\end{array}$ & $\begin{array}{l}\text { Weight loss } \\
\text { Thirst, polyuria }\end{array}$ & 52 \\
\hline $14 \dagger$ & M 22 & 3,4 & 96 & $\left\{\begin{array}{l}\text { RBG } 10.0 \text { mmol// } \\
\text { OGTT "impaired" }\end{array}\right.$ & $\begin{array}{r}364 \\
78\end{array}$ & Tiredness & 84 \\
\hline $15 t$ & M 43 & 3,4 & 62 & $\left\{\begin{array}{l}\text { RBG 9.4 mmol/ } \\
\text { OGTT "impaired" }\end{array}\right.$ & $\begin{array}{l}64 \\
56\end{array}$ & Asymptomatic & \\
\hline
\end{tabular}


diabetic brother. He was positive for islet cell antibody and for thyroglobulin and thyroid microsomal antibodies (thyroid function remained normal). An oral glucose tolerance test in February 1981 gave a normal result, though the insulin response was slightly reduced. A random blood glucose estimation in April 1984 was $7.3 \mathrm{mmol} / \mathrm{l}$ and the following April $8.7 \mathrm{mmol} / \mathrm{l}$; at the second estimation his glycosylated haemoglobin concentration was $6.3 \%$. A $25 \mathrm{~g}$ intravenous glucose tolerance test showed complete loss of first phase insulin response to glucose, and an oral glucose tolerance test showed him to be diabetic. Fasting blood glucose values were in the diabetic range on three other occasions $(7 \cdot 8,11 \cdot 0$, and $10 \cdot 1 \mathrm{mmol} / \mathrm{l})$ but he remained asymptomatic. Glibenclamide failed to reduce his hyperglycaemia and in September 1985 he started to lose weight. He began insulin 17 months after the first recording of a high random blood glucose concentration.

Case 14-A 22 year old man who was haploidentical with his diabetic younger brother had the following random blood glucose concentrations: October 1979, $10.0 \mathrm{mmol} / \mathrm{l}$; January $1980,8 \cdot 2 \mathrm{mmol} / \mathrm{l}$; and March 1980, $9.8 \mathrm{mmol} / \mathrm{l}$. In November 1980 an oral glucose tolerance test gave a normal result by WHO and National Diabetes Data Group criteria (figure). In

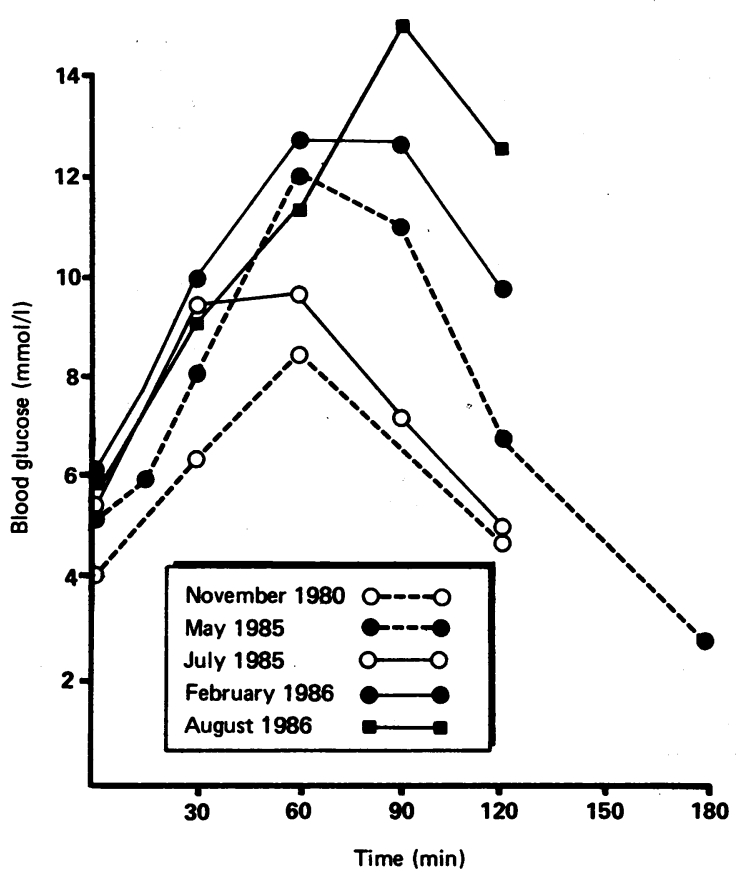

Case 14. Serial blood glucose responses to oral glucose tolerance test $(75 \mathrm{~g})$.

March 1985 he gave a six month history of tiredness; a random blood glucose concentration was $8.8 \mathrm{mmol} / \mathrm{l}$ but the glycosylated haemoglobin value was normal $(5 \cdot 4 \%)$. An intravenous glucose tolerance test showed a virtually absent first phase insulin response; the result of an oral glucose tolerance test was still normal by WHO criteria but showed impaired glucose tolerance by National Diabetes Data Group criteria. Further oral glucose tolerance tests were carried out in July 1985 and February 1986. By both criteria the first of these gave a normal result but the second showed impaired glucose tolerance. In August 1986 his glucose response was diabetic and his glycosylated haemoglobin concentration had risen to $7 \cdot 4 \%$; he remained, however, without any specific symptoms.

\section{Discussion}

Symptomatic insulin dependent diabetes is simple to diagnose, though in practice recognition is often delayed. In the survey of Hamilton et al of 66 newly presenting children 31 had attended their general practitioners more than once before diabetes was recognised; this included 11 of 17 children admitted with ketoacidosis. ${ }^{2}$ Childhood diabetes is uncommon in Britain (reported incidence $7 \cdot 7-13 \cdot 8$ cases per 100000 a year), though the incidence may be rising. ${ }^{8}$ Hence a general practitioner with an average list might see a new case only once in 14 years. In addition, the diagnosis may not be obvious in the early stages; in our study it was overlooked even by parents who already had one child with $\underline{\square}$ diabetes. Increased awareness of the possibility of diabetes and routine urine screening would undoubtedly prevent episodes of ketoacidosis and the occasional tragedy. For example, screening the $c$ urine of 38000 schoolchildren identified 18 new cases of diabetes. Even so, glycosuria may not be present with mild hyperglycaemia. $\overline{\bar{J}}$

Random blood glucose concentrations may be more useful; Lind and Anderson showed that the normal range for these is surprisingly $\$$ low. ${ }^{10}$ In pregnant women the $99 \%$ cut off values were $6.1 \mathrm{mmol} / 1 \mathrm{~m}$ within two hours of a meal and $5.6 \mathrm{mmol} / \mathrm{l}$ more than two hours. after. In our series, which included non-diabetic parents as well as $\vec{\Rightarrow}$ siblings, the $97.5 \%$ value was $6.3 \mathrm{mmol} / \mathrm{l}$, well below the normal renal threshold for glucose.

Several of our subjects appeared to have had intermittent $\frac{\bar{\sigma}}{\bar{\omega}}$ hyperglycaemia long before symptoms developed. One (case 14) continued to have normal oral glucose tolerance until five years $\varrho$ later, though unfortunately no tests were performed at times of the initial high random glucose values. This would be consistent with $\vec{\circ}$ the concept of recurrent attacks on pancreatic $\beta$ cells with fluctuating immune destruction and regeneration. ${ }^{11}$

The belief that the onset of glucose intolerance may be slow in type I diabetes is not new and there are isolated case reports of 3 . gradual deterioration in glucose tolerance. ${ }^{12}{ }^{13}$ Several studies haveĩ shown that testing glucose tolerance in children and adolescents will! identify a subgroup with impaired tolerance, but the rate of $\mathrm{G}$ progression to insulin dependent diabetes is low. The groups tested $\infty$ have been heterogeneous and almost certainly included subjects $\omega$ with maturity onset diabetes of the young. ${ }^{14}$ Rosenbloom et al $\vec{N}$ examined the 10 year prognosis of impaired glucose tolerance in음 siblings of children with diabetes and found that five of 19 such $V$ children had begun to receive insulin within the next seven years ${ }_{\mathbb{\Phi}}$ compared with one of 86 with a normal screening test result. ${ }^{150}$ Within the Pittsburgh study six subjects (two siblings and fouro parents) developed diabetes, of whom four needed insulin. Three of these had impaired glucose tolerance or a reduced insulin response $\vec{\theta}$ 18,22 , and 17 months before they began insulin. ${ }^{16}$

Indirect evidence that the onset may be slow comes from observed differences in height at diagnosis between diabetic and non-diabetic identical twins. ${ }^{17}$ There was no difference when diabetes was diagnosed over the age of 19 , but the diabetic twin was. shorter by a mean of $3.5 \mathrm{~cm}$ in eight of 16 presenting before this age. शे The average period of delayed growth before diagnosis was 35 weeks compared with a duration of symptoms of six weeks.

Not all cases of insulin dependent diabetes have such a prolonged onset, and the histories described reflect the wide clinical range within the disease. ${ }^{18}$ Only $10-15 \%$ of new patients have a first degree relative with insulin dependent diabetes, so our familial group may not be wholly representative. Nevertheless, there is little to suggest that they differ substantially from sporadic cases. It might be argued that our older subjects were not truly insulin dependent, as definition in this group is difficult. ${ }^{19}$ None, however, were obese (allo were $<110 \%$ of ideal body weight); all but two were positive for islet $₹$ cell antibody; and all possessed the HLA-DR antigens associated은 with insulin dependent diabetes. It has been suggested that patients N possessing HLA-DR3 without DR4 have a less abrupt clinical ${ }^{\circ}$ course, though only three of our subjects fell into this category. ${ }^{20}$ 음 Five patients had other autoantibodies and therefore might be considered to have had a primary autoimmune type of diabetes reported to have a slower onset. ${ }^{21}$

The search for possible causes of insulin dependent diabetes continues and interest has again focused on the Coxsackie B4 and B5읃 viruses. Raised titres of IgM antibodies to these have been detected in some $30 \%$ of newly diagnosed children. ${ }^{22}$ In view of the lengthy. prodrome recorded in our and other studies it seems likely that viral ${ }_{0}^{\circ}$ illnesses may act by precipitating rather than initiating the process $\stackrel{\overrightarrow{\mathbb{D}}}{\mathrm{D}}$ of $\beta$ cell destruction. ${ }^{23}$ This might explain the apparent clustering of $\frac{\text { }}{\mathbb{\Phi}}$ new cases presenting during viral epidemics and the seasonal $\varrho$ variation in onset of the disease..$^{24}$

If insulin dependent diabetes typically has a slow onset, as in our 8 series, early diagnosis would give the impression of a more benign? course over the first year. The remission or "honeymoon" phaseco reported in one third to a half of new cases ${ }^{25}$ may simply reflect? 
earlier diagnosis and treatment. Reports of clinical remission induced by immunosuppression have not taken this into account and future trials may need to be evaluated in this light. ${ }^{26}$ Early detection of metabolic abnormalities would improve the chances for success of intervention, but prediction at a much earlier stage (even before impaired glucose tolerance is found) would offer the best prospect of preserving viable numbers of functioning $\beta$ cells.

We thank the families for their enthusiastic cooperation over many years; Drs J Lister, R Scott, B Thomson, T Westcott, and others for referring patients; and Dr P L Drury for advice. The family study receives continued support from the British Diabetic Association. ACT and KMS were funded by the Medical Research Council. Further generous support has been received from the Leverhulme Trust and Novo Laboratories.

\section{References}

1 Jolly H. Diseases of children. Sth ed. Oxford: Blackwell, 1985:575.

2 Hamilton DV, Mundia SS, Lister J. Mode of presentation of juvenile diabetes. Br Med $\mathcal{J}$ 1976;ii:211-2.

3 Gorsuch AN, Spencer KM, Lister J, et al. The natural history of type I (insulin-dependent) diabetes mellitus: evidence for a long prediabetic period. Lancet 1981 ;i: $1363-5$.

4 Jackson RA, Morris MA, Haynes BF, Eisenbarth GS. Increased circulating Ia-antigen-bearing T cells in type 1 diabetes mellitus. N Engl f Med 1982;306:785-8.

5 Srikanta S, Ganda OP, Jackson RA, et al. Type 1 diabetes mellitus in monozygotic twins: chronic progressive beta cell dysfunction. Ann Intem Med 1983;99:320-6.

6 World Health Organisation. Diabetes mellitus. Report of a WHO study group. WHO Tech Rep Ser 1985; No 727.

7 National Diabetes Data Group. Classification and diagnosis of diabetes mellitus and other categories of glucose intolerance. Diabetes 1979;28:1039-57.

8 Patterson CC, Thorogood M, Smith PG, Heasman MA, Clarke JA, Mann JI. Epidemiology of type 1 (insulin-dependent) diabetes in Scotland 1968-1976: evidence of increasing incidence. Diaberologia 1983;24:238-43.

9 Sharkey TP, Troup P, Miller R, Van Kirk HC, Freeman R, Williams HH. Diabetes detection drive in Dayton, Ohio. JAMA 1950;144:914-9.

10 Lind T, Anderson J. Does random blood glucose sampling outdate testing for glycosuria in the detection of diabetes during pregnancy? Br Med $\mathcal{J}$ 1984;289:1569-71.

11 Spencer KM, Tarn A, Dean BM, Lister J, Bottazzo GF. Fluctuating islet-cell autoimmunity in unaffected relatives of patients with insulin-dependent diabetes. Lancet 1984;i:764-6.

12 Johansen K. Mild carbohydrate intolerance developing into classic juvenile diabetes. Acta Med Scand 1981;189:337-9.

13 Hales CN. Plasma-levels of glucose, non-esterified fatty acid, glycerol and insulin four years before the onset of diabetic ketoacidosis. Lancet 1967;ii:389-90.

14 Fajans SS, Floyd JC, Tattersall RB, Williamson JR, Pek S, Taylor CI. The various faces of diabetes in the young. Changing concepts. Arch Intern Med 1976;136:194-202.

15 Rosenbloom AL, Hunt SS, Rosenbloom EK, MacLaren NK. Ten-year prognosis of impaired glucose tolerance in siblings of patients with insulin-dependent diabetes. Diabetes 1982;31: 385-7.

16 Orchard TJ, Rosenbloom AL. The development of insulin-dependent diabetes mellitus among relatives. Diabeles Care 1985;8(suppl 1):45-50.

17 Hoskins PJ, Leslie RDG, Pyke DA. Height at diagnosis of diabetes in children: a study in identical twins. BrMed I 1985;290:278-80.

18 Lister J. The clinical spectrum of juvenile diabetes. Lancet 1966;ii:386-8.

19 Wilson RM, Van der Minne P, Deverill I, et al. Insulin dependence: problems with the ilson RM, Van der Minne P, Deverill I, et al. Insulin dependence:
classification of 100 consecutive patients. Diaberic Medicine 1985;2:167-72.

20 Ludvigsson J, Samuelsson U, Beauforts C, et al. HLA-DR3 is associated with a more slowly progressive form of type 1 (insulin-dependent) diabetes. Diabetologia 1986;29:207-10.

21 Bottazzo GF, Cudworth AG, Moul DJ, Doniach D, Festenstein H. Evidence for a primary autoimmune type of diabetes mellitus. $\mathrm{Br}$ Med $\mathcal{O}$ 1978;ii:1253-5.

22 Banatvala JE, Schernthaner G, Schober E, et al. Coxsackie B, mumps, rubella, and cytomegalo virus specific IgM responses in patients with juvenile-onset insulin-dependent diabetes mellitus in Britain, Austria, and Australia. Lancet 1985;i:1409-12.

23 Bottazzo GF. Death of a beta cell: homicide or suicide? Diaberic Medicine 1986;3:119-30.

24 Gamble DR, Taylor KW. Seasonal incidence of diabetes mellitus. Br Med J 1969;iii:631-3.

25 White P. Natural course and prognosis of juvenile diabetes. Diabetes 1956;5:445-50.

26 Stiller CR, Dupre J, Gent $M$, et al. Effects of cyclosporine immunosuppression in insulindependent diabetes mellitus of recent onset. Science 1984;223:1362-7.

(Accepted 28 November 1986)

\title{
Comprehensive care of patients with head injuries
}

\author{
GORDON BROCKLEHURST，MICHAEL GOODING，GARY JAMES
}

\begin{abstract}
The comprehensive head injury service run by the neurosurgeons at the Hull Royal Infirmary for the surrounding population of one million was analysed. The analysis showed that all patients with either a fractured skull or a lowered level of consciousness should be admitted to a district general hospital because the associated risk of their having a major head injury is over $20 \%$. Those patients with both a fractured skull and a lowered level of consciousness have a $60 \%$ likelihood of a major head injury and should be transferred immediately to the neurosurgical unit. Patients with compound or complicated fractures of the skull and those without fractured skulls but with neurological impairment persisting for four hours or more, should also be transferred to the neurosurgical unit.

If these guidelines are followed about 200 patients/million population will be referred to the neurosurgical centre. Patients
\end{abstract}

Neurosurgical Department, Royal Infirmary, Hull HU3 2JZ

GORDON BROCKLEHURST, MD, FRCS, consultant neurosurgeon

MICHAEL GOODING, MD, FRCS, consultant neurosurgeon

GARY JAMES, BSC, RGN, research assistant

Correspondence to: Mr Brocklehurst. with a minor head injury and none of the clinical risk factors may safely be sent home. This should reduce the rate of admissions to hospital for head injuries by $60 \%$.

\section{Introduction}

When the Royal Infirmary in Hull was opened in 1967 it was decided that all patients who required admission to hospital after a head injury would come directly under the care of the neurosurgeons. In addition to patients with obvious major head injuries, those with minor head injuries were admitted if they had the following signs: loss of consciousness (however brief); headache; and vomiting and unsteadiness, particularly in children. Skull radiographs were obtained for all patients with any kind of head injury, and radiological proof of a fractured skull was a further criterion for admission.

The neurosurgeons at this hospital have thus provided a clinical service for all patients with minor or major head injuries for the population on the north bank of the Humber (about 500000). During this time the neurosurgeons have also accepted all patients with head injuries referred to them from the two district general hospitals south of the Humber and other smaller hospitals around Hull. The total population served by these referring hospitals is also about 500000 (see figure). This combined service is part of a neurosurgical practice that has grown in recent years (see table I) with satisfactory results.

In the past two years the identification of several factors correlated with the risks of intracranial haematoma in patients with 